\title{
EDUKASI GIZI DENGAN PERMAINAN KOMUNIKATA TERHADAP PENGETAHUAN DAN SIKAP KONSUMSI SAYUR BUAH, JAJANAN DAN SARAPAN
}

\author{
Amanah, Ninda Risti ${ }^{\text {; }}$ Agung, Fred ${ }^{1}$; Par'l, Holil M. ${ }^{1}$; Fauziyah, Rr. Nur'; \\ Syahidatunnisa, Ulfah Sofindra ${ }^{1}$ \\ ${ }^{1} J u r u s a n$ Gizi, Politeknik Kesehatan Kementerian Kesehatan Bandung, \\ Email: nindaamanah@gmail.com
}

\begin{abstract}
ABSTRAK
Masalah konsumsi yang sering terjadi pada anak sekolah ialah anak-anak cenderung kurang mengonsumsi buah dan sayur, sering melewatkan sarapan pagi dan konsumsi jajanan yang tidak sehat. Tujuan dari penelitian ini adalah untuk mengetahui pengaruh edukasi menggunakan permainan komunikata terhadap pengetahuan dan sikap konsumsi sayur buah, makanan jajanan dan sarapan pada siswa kelas 4 . Desain penelitian yang digunakan adalah quasi eksperimen dengan model rancangan pre and post test control group design dengan sampel purposive sampling. Sampel berjumlah 17 orang untuk masing masing kelompok. Analisa data pada penelitian ini menggunakan uji $t$-dependen dan uji $t$-independen dengan uji alternatif Wilcoxon dan Mann Whitney. Hasil uji statistik pengetahuan didapatkan nilai $p=0,031(p \leq 0,05)$ yang berarti terdapat perbedaan selisih atau pengaruh pendidikan gizi terhadap pengetahuan menggunakan media permainan komunikata pada siswa sekolah dasar, untuk sikap didapatkan nilai $p$ sebesar 0,322 ( $p \leq 0,05)$ yang berarti tidak terdapat perbedaan selisih atau pengaruh pendidikan gizi terhadap sikap menggunakan media permainan komunikata pada siswa sekolah dasar. Bagi sekolah perlu adanya edukasi berulang menggunakan media komunikata dari pihak guru pada siswa disela kegiatan belajar mengajar mengenai pentingnya mengonsumsi sayur dan buah, makanan jajanan dan sarapan.
\end{abstract}

Kata kunci: Edukasi gizi, komunikata, pengetahuan, sikap, konsumsi sayur buah, makanan jajanan, sarapan

\begin{abstract}
Consumption problems that often occur in school children are children less to consume fruits and vegetables, often skip breakfast and consume unhealthy snacks. The purpose of this study was to determine the effect of education using Komunkata games on the knowledge and attitudes of consumption of fruits, snacks and breakfast in 4th grade students. The research design used was quasi experiment with pre and post test control group design models with purposive sampling samples. The sample amounted to 17 people for each group. Data analysis in this study used the t-dependent test and independent t-test with alternative Wilcoxon and Mann Whitney tests. The statistical test results of knowledge obtained $p=0.031(p \leq 0.05)$ which means that there are differences of nutritional education on knowledge using media communication games for elementary school students, for attitudes obtained $p$ value of $0.322(p \leq 0.05)$ which means there is no difference of nutrition education on attitudes using media communication games to elementary school students. For schools there is a need for repeated education using communication media from the teacher's side to student interrupted by teaching and learning activities about the importance of consuming vegetables and fruit, snacks and breakfast.
\end{abstract}

Key words: Nutrition education, komunikata , knowledge, attitude, consumption of fruit vegetables, snacks, breakfast 


\section{PENDAHULUAN}

Usia sekolah (usia 5 sampai 14 tahun), merupakan masa yang mengalami tumbuh kembang yang cepat. Namun, pemberian gizi pada usia ini biasanya tidak berjalan secara sempurna, sehingga dapat menimbulkan beberapa masalah gizi pada anak ${ }^{[1]}$.

Secara nasional prevalensi pendek pada anak umur 5-12 tahun adalah 30,7 persen (12,3\% sangat pendek dan $18,4 \%$ pendek). Prevalensi gemuk pada anak umur 5-12 tahun masih tinggi yaitu 18,8 persen, terdiri dari gemuk 10,8 persen dan sangat gemuk (obesitas) 8,8 sedangkan prevalensi kurus (menurut IMT/U) pada anak umur 5-12 tahun adalah 11.2 persen, terdiri dari 4,0 persen sangat kurus dan 7,2 persen kurus [2].

Masalah gizi dipengaruhi oleh banyak faktor dan bersifat kompleks, asupan makanan yang kurang dan penyakit infeksi yang tinggi merupakan dua faktor penyebab langsung kurang gizi. Asupan makanan sehari-hari sangat berpengaruh terhadap status gizi

Buah dan sayur merupakan sumber pangan yang bermanfat bagi kesehatan, perkembangan, pertumbuhan maka, sangat penting dikonsumsi terutama bagi anak-anak ${ }^{[3]}$. Walaupun demikian, saat ini banyak anak-anak cenderung kurang mengonsumsi buah dan sayur, seperti pada hasil riskesdas 2018 di Jawa Barat kurangnya konsumsi sayur buah pada penduduk $\geq 5$ tahun, sebanyak $98,2 \%{ }^{[4]}$.

Selain konsumsi buah dan sayur, sarapan juga merupakan salah satu asupan zat gizi yang penting. Kebiasaan sarapan merupakan anjuran pesan gizi seimbang. Bagi anak sekolah sarapan yang cukup terbukti dapat meningkatkan konsentrasi belajar dan stamina sehingga dapat meningkatkan prestasi belajar serta dapat memperbaiki status gizi anak dan mengoreksi defisiensi mikronutrien sehingga fungsi kognitif anak menjadi lebih baik. Berdasarkan analisis dari hasil survey Riskesdas tahun 2010 dapat diketahui bahwa dari 35.000 anak usia sekolah sekitar $26,1 \%$ sarapan hanya dengan air minum dan $44,6 \%$ memperoleh asupan energi kurang dari $15 \%$ kebutuhan gizi per hari.

Anak yang melewatkan sarapan akan merasakan lapar, maka meereka akan mengonsumsi makanan yang tinggi kalori yang berasal dari makanan jajanan. Selain berkalori tinggi pada makanan jajanan sering terdapat bahan tambahan pangan (BTP) yang sering disalahgunakan seperti dimasukannnya bahan kimia berbahaya Untuk memperoleh pangan yang bergizi dan aman, pemerintah melalui Peraturan Pemerintah (PP) No. 19 tahun 2005 tentang Standar Nasional Pendidikan (SNP) menyebutkan bahwa setiap lembaga pendidikan wajib memiliki sarana dan prasarana antara lain ruang kantin atau kantin sekolah ${ }^{[5]}$. Saat ini masih banyak lembaga pendidikan yang tidak dilengkapi kantin sekolah, terutama sekolah dasar.

Faktor lain yang mempengaruhi status gizi adalah perubahan perilaku. Perubahan perilaku ditentukan oleh faktor predisposisi yakni pengetahuan dan sikap ${ }^{[6]}$. Peningkatan pengetahuan tidak selalu menyebabkan terjadinya perubahan sikap dan perilaku tetapi mempunyai hubungan positif, yakni dengan peningkatan pengetahuan maka terjadinya perubahan sikap dan perilaku akan lebih cepat

Pendidikan gizi yang diberikan pada anak usia sekolah dasar diupayakan diberikan melalui media yang menarik agar penyampaian materi dapat diterima dengan lebih muda ${ }^{[7]}$. Metode permainan sangat cocok dalam memberikan pendidikan gizi di Sekolah Dasar terutama pengenalan gizi seimbang pada anak karena usia tersebut merupakan masa bermain. Sehingga, pemberian pengetahuan melalui permainan akan sangat efektif 
dalam peningkatan pengetahuan anak mengenai gizi seimbang ${ }^{[8]}$.

\section{METODE}

Jenis penelitian yang digunakan adalah Quasi Experiment dengan menggunakan rancangan control group pre and post test design. Bertujuan mengukur dampak intervensi terhadap pengetahuan dan sikap mengenai konsumsi sayur buah, makanan jajanan dan sarapan. Lokasi penelitian di SDN Cinunuk 1 dan SDN Cinunuk 8 Kabupaten Bandung yang dilaksanakan April 2019. Populasi adalah seluruh siswa kelas 4 SDN Cinunuk 1 dan SDN Cinunuk 8. Sampel adalah 17 orang siswa yang memenuhi kriteria inklusi.

Analisis data univariat untuk melihat karakteistik responden seperti usia, dan jenis kelamin. Analisis bivariat dilakukan untuk mengetahui pengaruh intervensi menggunakan media permainan komunikata terhadap pengetahuan dan sikap siswa sekolah dasar kelas 4 mengenai konsumsi sayur buah, makanan jajanan dan sarapan. Uji normalitas yang digunakan adalah Shapiro Wilk. Jika data terdistribusi normal diuji menggunakan uji $T$ Independen dan uji T-dependen. Bila data tidak terdistribusi normal diuji menggunakan uji Wilcoxon dan uji Mann Whitney.

\section{HASIL}

Penelitian dilakukan di dua sekolah bereda yaitu SDN Cinunuk 1 sebagai kelompok perlakuan dan SDN Cinunuk 8 sebagai kelompok kontrol.

Tabel 1. Distribusi Frekuensi Karakteristik Umum Sampel

\begin{tabular}{lcccc}
\hline & \multicolumn{2}{c}{ Perlakuan } & \multicolumn{2}{c}{ Kontrol } \\
\cline { 2 - 5 } & $\mathrm{N}$ & $\%$ & $\mathrm{~N}$ & $\%$ \\
\hline Jenis kelamin & 8 & 47,1 & 11 & 35,3 \\
Laki-Laki & 9 & 52,9 & & 64,7 \\
Perempuan & 1 & 5,9 & 0 & 0 \\
\hline Umur & 16 & 94,1 & 5 & 29,4 \\
9 tahun & 0 & 0 & 12 & 70,6 \\
10 tahun & & & & \\
11 tahun & & &
\end{tabular}

Berdasarkan tabel 1 dapat diketahui bahwa jumlah sampel kelompok perlakuan sebanyak 17 orang dengan jenis kelamin laki-laki 8 orang $(47,1 \%)$ dan perempuan 9 orang (52,9\%). Pada kelompok kontrol jumlah sampel sebanyak 17 rang dengan jenis kelamin

Tabel 2. Perubahan Pengetahuan Konsumsi Buah Sayur, Makanan Jajanan, dan Sarapan Pre-Post Test pada Kelompok Perlakuan dan Kelompok Kontrol

\begin{tabular}{cccccc}
\hline \multirow{2}{*}{ Pengetahuan } & \multicolumn{2}{c}{ Sebelum } & \multicolumn{2}{c}{ Sesudah } & \multirow{2}{*}{ Nilai $p$} \\
\cline { 2 - 5 } & Median & Min-Max & Median & Min-Max & \\
\hline Perlakuan & 80,00 & $46,67-93,33$ & 93,33 & $80,00-100,00$ & $<0,001$ \\
\hline Kontrol & 86,66 & $46,67-93,33$ & 86,66 & $53,33-100,00$ & 0,004 \\
\hline
\end{tabular}

laki-laki 6 orang $(35,3 \%)$ dan perempuan 11 orang (64,7\%). Berdasarkan distribusi frekuensi kelompok usia didapatkan kategori usia paling banyak adalah 10 tahun.
Pada tabel 2 menunjukan hasil uji statistik, uji statistik yang digunakan adalah uji Wilcoxon. Dari hasil uji tersebut menunjukkan terdapat perubahan pengetahuan yang bermakna pada sebelum intervensi dan setelah intervensi baik pada kelompok perlakuan dengan nilai $p<0,001$ dan kelompok kontrol dengan nilai $p=0,004$. 
Jurnal Riset Kesehatan

Poltekkes Kemenkes Bandung

Volume 11 No.1 Tahun 2019

Tabel 3. Perubahan Sikap Konsumsi Buah Sayur, Makanan Jajanan, dan Sarapan pada Kelompok Perlakuan dan Kelompok Kontrol

\begin{tabular}{cccccc}
\hline \multirow{2}{*}{ Sikap } & \multicolumn{2}{c}{ Sebelum } & \multicolumn{2}{c}{ Sesudah } & \multirow{2}{*}{ Nilai $p$} \\
\cline { 2 - 5 } & Median & Min-Max & Median & Min-Max & \\
\hline Perlakuan & 93,33 & $53,33-100,00$ & 100,00 & $60,00-100,00$ & $<0,001$ \\
\hline Kontrol & 100,00 & $73,33-100,00$ & 100,00 & $86,67-100,00$ & 0,066 \\
\hline
\end{tabular}

*Wilcoxon

Pada tabel 3 menunjukan hasil Uji statistic, uji statistik yang digunakan adalah uji Wilcoxon. Dari hasil uji tersebut menunjukkan terdapat perubahan sikap yang bermakna pada sebelum intervensi dan setelah intervensi pada kelompok perlakuan dengan nilai $p<0,001$, namun pada kelompok kontrol tidak terdapat perbedaan perubahan sikap yang bermakna sebelum dan sesudah intervensi dengan nilai $p=0,066$.

Tabel 4. Perbedaan Perubahan Pengetahuan Konsumsi Buah Sayur, Makanan Jajanan, dan Sarapan Pre-Post Test pada Kelompok Perlakuan dan Kelompok Kontrol

\begin{tabular}{ccccc}
\hline Variabel & Kelompok & Median & Min-Max & Nilai $p$ \\
\cline { 2 - 4 } Pengetahuan & Perlakuan & 93,33 & $80,00-100,00$ & \multirow{2}{*}{0,031} \\
\cline { 2 - 4 } & Kontrol & 86,66 & $53,33-100,00$ &
\end{tabular}

${ }^{*}$ Mann Whitney

Antar dua kelompok sampel dilakukan perlakuan yang berbeda untuk melihat perbedaan dari media yang diberikan. Dari tabel 4 terlihat hasil uji Mann Whitney menyimpulkan bahwa ada perbedaan perubahan pengetahuan yang bermakna antara kelompok perlakuan dan kelompok kontrol dengan nilai $p=0,031$. Dapat disimpulkan bahwa penyuluhan dengan tambahan media komunikata lebih efektif untuk meningkatkan pengetahuan dibandingkan penyuluhan dengan media power point.

Tabel 5. Perbedaan Perubahan Sikap Konsumsi Buah Sayur, Makanan Jajanan, dan Sarapan PrePost Test pada Kelompok Perlakuan dan Kelompok Kontrol

\begin{tabular}{ccccc}
\hline Variabel & Kelompok & Median & Min-Max & Nilai $p$ \\
\hline \multirow{2}{*}{ Sikap } & Perlakuan & 93,33 & $80,00-100,00$ & \multirow{2}{*}{0,322} \\
\cline { 2 - 4 } & Kontrol & 86,66 & $53,33-100,00$ & \\
\hline
\end{tabular}

*Mann Whitney

Dari tabel 5 terlihat hasil uji Mann Whitney menyimpulkan bahwa tidak ada perbedaan perubahan pengetahuan yang bermakna antara kelompok perlakuan dan kelompok kontrol dengan nilai $p=0,322$. Dapat

\section{PEMBAHASAN}

\section{Karakteristik Umur Sampel}

Kelompok perlakuan lebih banyak sampel yang berjenis kelamin perempuan dengan jumlah 9 orang dan laki-laki berjumlah 8 orang. Pada kelompok kontrol pun lebih banyak sampel yang berjenis kelamin disimpulkan bahwa penyuluhan dengan tambahan media komunikata tidak lebih efektif untuk meningkatkan pengetahuan dibandingkan penyuluhan dengan media power point.

perempuan dengan jumlah 11 orang dan laki-laki berjumlah 6 orang.)

Usia sampel dalam penelitian ini berkisar antar 9-11 tahun. Hal tersebut karena usia anak yang sesuai untuk diberikan pendidikan gizi adalah anak yang berada pada periode 6-14 tahun, karena pada usia ini anak ulai matang secaraseksual dan matang untuk belajar 
serta merupakan periode intelektual. Dari rentang usia tersebut anak berada dalam tahapan operasional formal, yaitu mampu untuk berpikir secara abstrak, menalar secara logis, dan menarik kesimpulan dari informasi yang tersedia.

\section{Perubahan Pengetahuan dan Sikap Konsumsi Buah Sayur, Makanan Jajanan dan Sarapan pada Kelompok Perlakuan dan Kontrol}

Berdasakan hasil analisa perbedaan tingkat pengetahuan konsumsi sayur buah, makanan jajanan dan sarapan dengan menggunakan media permainan komunikata pada kelompok perlakuan diperoleh hasil $(p<0,001)$. Dapat disimpulkan bahwa ada perbedaan yang bermakna rata-rata nilai pengetahuan sebelum dan sesudah intervensi setelah diberikan penyuluhan menggunakan media permainan komunikata. Hal ini sejalan dengan penelitian Hidayat (2013), bahwa penyuluhan menggunakan media dapat meningkatkan pengetahuan gizi anak secara signifikan ${ }^{[9]}$. Media permainan sangat cocok dalam memberikan pendidikan mengenai gizi pada anak sekolah dasar karena masa anak-anak merupakan masa bermain ${ }^{[8]}$. Penggunaan media permainan komunikata dalam penelitian ini membuat siswa mendapatkan pengetahuan dengan cara yang menyenangkan, yakni belajar sambil bermain. Dengan menggunakan permainan komunikata tersebut, siswa akan mendengarkan materi secara berulang selama permainan mempermudah siswa untuk mengingat materi mengenai konsumsi sayur buah, makanan jajanan dan sarapan yang terdapat dalam permainan komunikata.

Berdasarkan hasil analisis, perbedaan tingkat pengetahuan konsusi sayur buah, makanan jajanan dan sarapan pada kelompok kontrol diperoleh hasil $(p=0,004)$. Dapat disimpulkan bahwa ada perbedaan yang bermakna rata-rata nilai pengetahuan sebelum dan sesudah intervensi setelah diberikan penyuluhan menggunakan media power point. Dengan menggunakan media power point pun dapat meningkatkan pengetahuan mengenai gizi seimbang. Hal ini sejalan dengan penelitian Rizki (2018) terdapat perubahan pengetahuan yag signifikan sebelum dan setelah penyuluhan dengan media power point $(p=0,02)^{[10]}$. Dan hasil penelitian Zul Salasa (2013) menyatakan bahwa penyuluhan yang diberikan dapat peningkatan pengetahuan dan sikap pada sampel akibat dari intervensi melalui penyuluhan dengan metode ceramah. Metode ceramah memiliki keuntungan adanya komunikasi dua arah antara penyuluh dan pertanyaan dari sampel menjadikan sampel lebih memahami dari materi yang disampaikan penyuluh $^{[11]}$.

Berdasakan hasil analisa, perbedaan sikap konsumsi sayur buah, makanan jajanan dan sarapan dengan menggunakan media permainan komunikata pada kelompok perlakuan diperoleh hasil $(p<0,001)$. Dapat disimpulkan bahwa ada perbedaan yang bermakna rata-rata nilai sikap sebelum dan sesudah intervensi setelah diberikan penyuluhan menggunakan media permainan komunikata. Hal ini sejalan dengan penelitian Pratiwi (2013) bahwa adanya perubahan sikap setelah diberikan penyuluhan menggunakan media permainan kuis $(p=0,000){ }^{[12]}$. Hal ini juga dikuatkan oleh teori bahwa proses belajar dipengaruhi oleh beberapa faktor meliputi materi yang dipelajari, lingkungan pembelajaran, alat yang digunakan untuk membantu dalam proses belajar, dan kondisi individu [12]. Media permainan dapat menjadi alat bantu dalam proses belajar dimana siswa ikut berpartisipasi dan berperan aktif.

Perbedaan Perubahan Pengetahuan Konsumsi Buah Sayur, Makanan Jajanan dan Sarapan Pre-Post Test pada Kelompok Perlakuan dan Kelompok Kontrol 
Berdasarkan hasil analisisi, diperoleh hasil $(p=0,031)$, maka ada perbedaan yang bermakna antara selisih rata-rata kelompok perlakuan dan kelompok kontrol setelah dilakukan intervensi dengan media pemainan komunikata. Dapat disimpulkan bahwa ada pengaruh penyuluha nmenggunakan permainan komunikata terhadap pengetahuan konsumsi sayur buah, makanan jajanan dan sarapan. $\mathrm{Hal}$ ini sejalan dengan hasil penelitian Kurnia (2018) menunjukkan bahwa penggunaan media ular tangga pada kegiatan penyuluhan berpengaruh terhadap pengetahuan mengenai gizi pada siswa sekolah dasar dengan nilai $\mathrm{p}=0,011^{[13]}$.

Pengetahuan seseorang memiliki tingkat yang berbeda beda, yaitu tahu, memahami, aplikasi, analisa, sintesis dan evaluasi ${ }^{[14]}$. Sampel dalam kelompok pelakuan maupun kontrol baru mencapai tingkat memahami. Memahami bukan sekedar tahu terhadap objek tersebut, tidak hanya menyebutkan tetapi dapat menjelaskan dan menyebutkan contoh. Dalam kelompok perlakuan maupun kontrol sampel mampu menyebutkan dan contoh dan menjelaskan saat sesi tanya jawab. Menurut Notoatmodjo (2015) pengetahuan merupakan hasil penginderaan manusia atau hasil dari tahu seseorang setelah melakukan penginderaan terhadap suatu objek tertentu. Penginderaan terjadi melalui panca indera manusia, yakni indera penglihatan, penciuman, rasa, dan raba, sebagian besar pengetahuan manusia diperoleh melalui mata dan telinga. Saat memainkan komunikata yang sebagian besar yang digunakan adalah telinga, dimana dalam bermain sampel mendengarkan pernyataan yang dibacakan dan memperhatikan penjelasan yang dijelaskan oleh peneliti. Penggunaan media permainan komunikata dalam penelitian ini membuat siswa mendapatkan pengetahuan dengan cara yang menyenangkan, yakni belajar sambil bermain. Selain itu, dengan menggunakan media permainan peserta ikut berpartisipasi sehinga labih mudah untuk mengingat dan meningkatkan pengetahuan dibandingkan hanya menggunakan media power point, dimana peserta kurang berpartisipasi.

\section{Perbedaan Perubahan Sikap Konsumsi Buah Sayur, Makanan Jajanan dan Sarapan Pre-Post Test pada Kelompok Perlakuan dan Kelompok Kontrol}

Sikap merupkan respon tertutup seseorang terhadap stimulus atau objek. Sikap belum merupakan tindakan atau aktifitas, namun merupakan predisposisi tindakan suatu perilaku. Sikap merupakan suatu sindroma atau kumpulan gejala dlam merespon stimulus atau objek, sehingga sikap itu melibatkan pikiran, perasaan, perhatian dan gejala kejiwaan lainnya. Selain itu, sikap dapat diartikan sebagai kesiapan untuk reaksi terhadap objek dilingkungan tertentu sebagai suatu penghayatan terhadap suatu objek

Berdasarkan hasil analisis, diperoleh hasil $(p=0,322)$, maka tidak ada perbedaan yang bermakna antara selisih rata-rata kelompok perlakuan dan kelompok kontrol setelah dilakukan intervensi dengan media pemainan komunikata. Dapat disimpulkan bahwa tidak ada pengaruh penyuluhan menggunakan permainan komunikata terhadap sikap konsumsi sayur buah, makanan jajanan dan sarapan. Hal ini sejalan dengan penelitian Marisa (2014) bahwa tidak terdapat perbedaan yang bermakna terhadap penngkatan sikap mengenai gizi seimbag pada kelompok perlakuan dan kelompok kontrol. Peningkatan sikap apabila dbandingkan antar kelompok, menunjukkan hasil bahwa tidak ada perbedaan yang bermakna. Pada kedua kelompok tesebut terjadi peningkatan yang relatif sama, meskipun kelompok kontrol lebih sedikit menerima edukasi dibandingkan kelompok perlauan yang diberikan 
tambahan edukasi berupa permainan komunikata. Hal ini dapat dikarenakan sikap tidak selalu dipengaruhi oleh pengetahuan. Seseorang dapat memiliki sikap yang baik meskipun tidak mengetahui ilmu, alasan atau latar belakang dari suatu sikap yang dipilih tersebut secara baik dan benar ${ }^{[15]}$.

\section{SIMPULAN}

Didapatkan nilai signifikansi sebesar 0,031 yang berarti terdapat perbedaan selisih atau pengaruh pendidikan gizi terhadap pengetahuan menggunakan media permainan komunikata pada siswa sekolah dasar. Perubahan sikap memiliki nilai signifikansi sebesar 0,322 yang berarti tidak terdapat perbedaan selisih atau pengaruh pendidikan gizi terhadap sikap menggunakan media permainan komunikata pada siswa sekolah dasar. Maka disarankan adanya edukasi menggunakan media komunikata mengenai pentingnya mengonsumsi sayur dan buah, makanan jajanan dan sarapan

\section{DAFTAR RUJUKAN}

1. Nuryanto, Pramono A, Puruhita $\mathrm{N}$, Fatimah Muis S. Pengaruh pendidikan gizi terhadap pengetahuan dan sikap tentang gizi anak Sekolah Dasar. J Gizi Indonesia. 2015;3(1):1858-4942.

2. Kemenkes RI. RISET KESEHATAN DASAR. 2013.

3. Mohammad A, Madanijah S. Konsumsi Buah dan Sayur Anak Usia Sekolah Dasar di Bogor. J. Gizi Pangan. Maret 2015; 10(1): 71-76

4. Kemenkes RI. RISET KESEHATAN DASAR. 2018

5. Kementrian Kesehatan RI. Pedoman keamanan pangan di Sekolah Dasar. Jakarta: Direktorat Bina Gizi, Ditjen Bina Gizi Dan Kesehatan Ibu Dan Anak, Kementrian Kesehatan. 2011

6. Achadi ED. Sekolah Dasar Pintu Masuk Perbaikan Pengetahuan,
Sikap, dan Perilaku Gizi Seimbang Masyarakat. J Kesehat Masy Indones [Internet]. 2010;5(1):42-7. Available from: http://jurnalkesmas.ui.ac.id/index. php/kesmas/article/download/16 1/162

7. Marisa. Pengaruh Pendidikan Gizi Melalui Komik Gizi Seimbang Terhadap Pengetahuan Dan Sikap Pada Siswa Sdn Bendungan Di Semarang. 2014

8. Yuli, Asmi Astuti. Pengaruh Pendidikan Gizi Metode Lari Estafet Terhadap Pengetahuan Gizi Seimbang Murid kelas V Di SDN 19 Kecamatan Luhak Nan Duuo kabupaten Pasaman Barat Tahun 2016. Skripsi Universitas Andalas.2016.

9. Hidayat, Hadi. Pengaruh Pendidikan gizi melalui Diskusi dan Permainan Edukatif Kubus Bergambar Terhadap Pengetahuan Gizi Seimbang Siswa Sekolah Dasar Kabupaten Bogor. Bogor; IPB. 2013

10. Rizki, Annisa Dyah. Hidayat, hadi. Efektivitas Penyuluhan Gizi MenggunakanMedia Slide Power Point dan poster Terhadap Pengetahuan Tentanf Sarapan Pagi Pada Anak Usia Sekolah. Jogjakarta; Poltekkes Jogja. 2018.

11. Zul Salasa. Pengaruh Penyuluhan Dengan Metode Ceramah dan Diskusi Terhadap Peningkatan Pengetahuan dan Sikap Anak Tentang Perilaku Hidup Bersih dan Sehat di Sekolah Dasar Negeri 0605014 Kelrahan Namogajah Kecamatan Medan Tuntungan Medan. 2013.

12. Pratiwi, Riskasari. Perbedaan Sikap Siswa Usia 6-12 Tahun Dalam Pencegahan Tuberkulosis Paru Melalui Pemberian Pendidikan Kesehatan Dengan Strategi Quiz Team Di Sdn Kasiyan Timur 01 Kecamatan Puger Kabupaten Jember.2013. 
13. Kurnia, Arif Rahmat. Pengembangan Ular Tangga Gizi Seimbang Sebagai Tumpeng Gizi Seimbang Pada Siswa sekolah dasar. Jurnal Dunia Gizi. 2018;1(2):65-70

14 Notoatmodjo, Soekidjo. Promosi Kesehatan Teori dan Aplikasi, Jakarta: Rineka Cipta. 2011.
15. Marisa, Nuryanto. Pengaruh Pendidikan Gizi Melalui Komik Gizi Seimbang Terhadap Pengetahuan dan Sikap Pada Siswa SDN Bendungan di Semarang. Journal of Nutrition College. 2014. 3(4).925-932. 